\title{
Effects of body size on male mating tactics and paternity in black bears, Ursus americanus
}

\author{
Adrienne I. Kovach and Roger A. Powell
}

\begin{abstract}
The reproductive behaviour of large, solitary mammals is difficult to study. Owing to their secretive nature and wide-ranging habits, aspects of male mating behaviour are poorly documented in solitary than in social species. We used radiotelemetry and microsatellite DNA analysis to investigate the influence of body size on male mating tactics and short-term reproductive success in the black bear, Ursus americanus, a solitary carnivore. We investigated male ranging behaviour and documented male encounters with breeding females to determine whether males employed conditional mating tactics according to their body sizes. We found that male home-range sizes were not positively associated with body size, but encounter rates with breeding females were. Although all males searched widely for females, mating access appeared to be largely determined by fighting ability. Large males encountered more breeding females and had more frequent encounters during the females' estimated receptive periods than did small- and medium-sized males. Paternity was highly skewed toward the three dominant males who fathered $91 \%$ of the cubs sampled during the 3 -year study. Paternity was correlated with the frequency of male encounters during female receptive periods. Male encounters, however, overestimated the success of medium-sized males and underestimated the overall variance in male reproductive success. Multiple paternity occurred in two of seven litters, indicating that sperm competition is important in black bear mating behaviour. Implications for male lifetime reproductive success are discussed.
\end{abstract}

Résumé : Le comportement reproducteur de grands mammifères solitaires est difficile à étudier. À cause de la nature discrète et des habitudes nomades des mâles des espèces solitaires, plusieurs aspects de leur comportement reproducteur sont beaucoup moins bien connus que chez les espèces sociales. Nous avons utilisé la radiotélémétrie et l'analyse des microsatellites de l'ADN pour étudier l'influence de la taille du corps sur les tactiques d'accouplement du mâle et sur le succès à court terme de la reproduction chez l'ours noir, Ursus americanus, un carnivore solitaire. Nous avons déterminé les comportements de déplacement des mâles et analysé les rencontres des mâles avec des femelles en état de reproduction pour voir si les mâles utilisent des tactiques conditionnelles d'accouplement en fonction de leur taille. Les surfaces des domaines vitaux des mâles ne sont pas en corrélation positive avec leur taille corporelle, mais leurs taux de rencontre de femelles le sont. Bien que tous les mâles fassent des recherches à grande échelle pour trouver des femelles, l'accès aux femelles semble être largement déterminé par leur capacité de lutte. Les grands mâles rencontrent plus de femelles reproductrices et font plus de contacts durant les périodes apparemment réceptives des femelles que ne le font les mâles de petite et moyenne tailles. La paternité est fortement asymétrique et est le fait principalement de trois mâles qui ont engendré $91 \%$ des oursons examinés durant notre étude de 3 ans. Il y a une corrélation entre la paternité et la fréquence des rencontres de femelles durant leurs périodes réceptives. Les rencontres faites par les mâles surestiment cependant le succès des mâles de taille intermédiaire et sous-estiment la variance globale du succès de la reproduction des mâles. Des paternités multiples se sont produites dans deux des sept portées, ce qui indique que la compétition spermatique est un facteur important dans le comportement reproducteur des ours noirs. Les conséquences de ces résultats sur le succès reproductif des mâles au cours de leur vie font l'objet d'une discussion.

[Traduit par la Rédaction]

\section{Introduction}

Among the many factors that contribute to male reproductive success, body size is one of the most important (McElligott et al. 2001). Intrasexual selection, in the form of

Received 8 January 2003. Accepted 20 May 2003. Published on the NRC Research Press Web site at http://cjz.nrc.ca on 27 August 2003.

A.I. Kovach ${ }^{\mathbf{1 , 2}}$ and R.A. Powell. Department of Zoology, North Carolina State University, Raleigh, NC 27695, U.S.A.

${ }^{1}$ Corresponding author (email: adrienne.kovach@unh.edu). ${ }^{2}$ Present address: Department of Zoology, Rudman Hall, 46 College Rd., University of New Hampshire, Durham, NH 03824, U.S.A. male-male competition, favours traits that confer on males an advantage in gaining access to females (Darwin 1871; Andersson 1994). Large body size is one such trait that is favoured because of its advantages to males during combat, endurance rivalry, or sperm competition (Andersson 1994). Large male size might also be favoured by intersexual selection if females prefer large males. Although male mating success may be influenced by other factors, such as search ability, that are independent of body size, the relative importance of those factors depends on the role of fighting in male-male competition (Schwagmeyer 1988). When male mating success is influenced strongly by fighting, sexual selective pressures promote sexual size dimorphism resulting in males that are larger than females (although the opposite pattern of dimorphism may evolve in species influenced by 
different selective pressures, e.g., spotted hyenas, Crocuta crocuta; Frank 1986). Sexual size dimorphism has been linked to mating systems in many mammalian taxa, and the degree of polygyny strongly influences the extent of sexual size dimorphism (Weckerly 1998). Among highly polygynous and sexually dimorphic mammals, therefore, male reproductive success is expected to be biased towards a few large adults with superior competitive abilities who are able to monopolize access to females, either through winning agonistic encounters or by attaining high social rank (Dewsbury 1982; Clutton-Brock 1988; Ellis 1995). Although this expectation has been confirmed for many species by genetic analyses (e.g., Pemberton et al. 1992; Hoelzel et al. 1999; Wilson et al. 2002), many exceptions have also been documented (e.g., Coltman et al. 1998, 1999; Gemmell et al. 2001; Engh et al. 2002). The extent to which large and dominant males are actually able to monopolize breeding success in different mammalian guilds, therefore, warrants reevaluation.

To date, the determinants of male reproductive success have been investigated primarily in social species. Male reproductive success might be influenced by different factors in solitary species than in social species. For example, it might be less dependent on body size and more strongly influenced by home range and search ability (Madsen et al. 1993; Fisher and Lara 1999). Male reproductive success in solitary species is also expected to be less skewed than in social species, owing to the dispersion of females and the resulting difficulty for males to monitor or guard multiple females (Emlen and Oring 1977; Clutton-Brock 1989).

In this study, we investigated the effects of body size on the reproductive behaviour of male black bears, Ursus americanus, in the southern Appalachian Mountains. Black bears have a spatial organization similar to that of many other solitary carnivores (e.g., other ursids, most mustelids, and felids). Males have large, overlapping home ranges that encompass the home ranges of several females (Barber and Lindzey 1986; Rogers 1987; Powell et al. 1997). Males search widely for and attempt to mate with several females sequentially ("roaming male tactic"; Sandell 1989). Females exhibit asynchronous oestrus, which results in a male-biased operational sex ratio (Emlen and Oring 1977), so that few females are receptive simultaneously and several males compete for access to each receptive female (Bunnell and Tait 1981). In spite of the dispersed spatial organization, a moderate potential exists for one or a few males to monopolize access to most females. Overt competition is thought to determine mating success, whereas search ability may be important for locating oestrous females (Rogers 1987). Frequent observations of bear-inflicted wounds (fresh lacerations and puncture wounds) on males during the breeding season indicate that fighting is important in mating success (LeCount 1982; Garshelis and Hellgren 1994; Powell et al. 1997; but see Barber and Lindzey (1986) for a population with a stable dominance hierarchy). Dual paternity of offspring within a litter has been documented, indicating that sperm competition is another facet of male-male competition (Schenk and Kovacs 1995).

Sexual size dimorphism is pronounced in black bears. Females grow faster, reach asymptotic size and sexual maturity earlier, and are, on average, 20-40\% smaller than males with respect to several size parameters, including body length, zygomatic width, and forefoot pad width (McRoberts et al. 1998). In the southern Appalachians, black bears have faster growth rates and reach sexual maturity at a younger age than in many northern populations (Powell et al. 1997). Females breed for the first time at 2-3 years of age, stop growing by age 4 , and usually weigh 40-75 kg. Males become sexually mature by at least 3 years of age but continue growing until they are at least 8 years of age and weigh $140-160 \mathrm{~kg}$. As a result, the largest adult males are three times heavier than the smallest ones in the population (Powell et al. 1997). Since competitive ability is determined by age and size, young and small male bears are at a disadvantage in fighting for mates and might adopt alternative mating tactics.

Male animals of many taxa, including some solitary carnivore species, employ condition-dependent mating tactics whereby individuals choose the tactic that confers the greatest fitness based on their phenotypes (Dominey 1984; Gross 1996). For example, rather than roaming widely in pursuit of numerous females, as the large males do, small male stoats, Mustela ermina, use small search areas containing few females (Sandell 1986, 1989). Through closely monitoring the reproductive conditions of the few females within their small home ranges, the competitively inferior small males increase their chances of gaining mating access prior to the large males. Similar condition-dependent tactics are predicted to occur in other solitary, promiscuous carnivores including black bears (Sandell 1989). A simulation model of black bear mating behaviour predicts a positive relationship between the sizes of males' breeding home ranges, the number of females they encounter, and their competitive abilities (Powell et al. 1997).

We investigated male ranging behaviour in a population of wild black bears to determine if males employed conditiondependent mating tactics according to their body sizes. We also conducted a genetic analysis of paternity to compare the relative success of the mating tactics and to determine if body size and ranging behaviour are reliable predictors of paternity. With the data, we tested the following hypotheses: (i) the size of a male's home range and his encounter rate with breeding females are both a function of body size, (ii) large males father the majority of offspring in the population, (iii) male encounters with breeding females are positively associated with paternity.

\section{Materials and methods}

\section{Study area}

In 1993-1995, we studied a population of black bears in the Pisgah Bear Sanctuary (PBS) in western North Carolina (U.S.A.) approximately $35 \mathrm{~km}$ southwest of Asheville, N.C. The sanctuary occupies an area of $220 \mathrm{~km}^{2}$ of the Pisgah National Forest within which bear hunting is illegal, although other game species can be hunted or trapped during legal seasons. Elevations within the study area range from 650 to $1750 \mathrm{~m}$. The Blue Ridge Parkway bisects the study area, at an elevation of approximately $1500 \mathrm{~m}$, making data collection feasible in the mountainous terrain. Powell et al. (1997) described the habitat of the sanctuary. 


\section{Trapping and sampling}

In May-August 1993-1995, we live-trapped bears using Aldrich foot snares modified for bear safety (Johnson and Pelton 1980). We anaesthetized trapped bears by blowgun or jabstick with a drug combination of ketamine hydrochloride $\left(\sim 200 \mathrm{mg} / \mathrm{cm}^{3}\right)$ and xylazine hydrochloride $\left(\sim 100 \mathrm{mg} / \mathrm{cm}^{3}\right)$ at a dosage of approximately $0.04 \mathrm{~cm}^{3} / \mathrm{kg}$ estimated body mass (Cook 1984). Each anaesthetized bear was weighed and measured, marked with ear tags, and tattooed on its upper lip and groin. We also extracted a first premolar tooth to estimate age and collected blood and ear tissue samples for genetic analyses. Tissue samples were placed on ice immediately after collection in the field and frozen at $-20^{\circ} \mathrm{C}$. We outfitted most bears $\geq 2$ years of age $(n=32)$ with 800 -g motion-sensitive radio-transmitter collars (Telonics, Mesa, Ariz.; Lotek Inc., Newmarket, Ont.). After 30-45 min of handling and data collection, bears were released and allowed to recover from the anaesthesia at the capture site.

\section{Classification of females and males}

In the PBS, the majority of female black bears reach sexual maturity at age 2 . We considered all females $\geq 2$ years of age to be breeding females, unless they were in lactational anoestrus. We confirmed this with physical examination for signs of oestrus (vulval swelling) upon capture. Black bears have delayed implantation and all females give birth to cubs at approximately the same time in late January. Therefore, backdating with gestation length from the point of birth to conception is not informative in estimating oestrus.

We placed males into three size classes based on their masses when captured in spring or early summer. Males that weighed 135-170 kg (ages 6-9) were classified as large males $(n=4)$. One large male (No. 340) dispersed immediately from the study area; radiotelemetry data were collected from the other three large males for two seasons. Males weighing $90-135 \mathrm{~kg}$ (ages 4-7) were classified as mediumsized males $(n=5)$. Radiotelemetry data were collected from all five for at least one season. Males weighing 35$90 \mathrm{~kg}$ (ages 2-3) were classified as small males $(n=14)$. Radiotelemetry data were collected from nine of them for at least one season. We considered all males $\geq 2$ years of age to be potential breeders (Powell et al. 1997).

\section{Radiotelemetry}

During the breeding season (mid-May through midAugust), we used standard radiotelemetry methods with triangulation to locate radio-collared bears (Powell et al. 1997). We radio-tracked bears for $8-12 \mathrm{~h}$ daily, primarily during the bears' active periods (early and late daylight hours). Successive locations of the same bear were normally separated by approximately $2 \mathrm{~h}$, and we attempted to locate all radio-collared bears during each 2 -h period. We estimated home ranges of all bears using a fixed kernel estimator, with band width determined using least squares crossvalidation (KERNELHR; Seaman et al. 1998).

We estimated males' encounters with females using radiotelemetry. Both the solitary and secretive nature of black bears and the mountainous and heavily wooded terrain of the study area prohibited direct observations of mating behaviour. Owing to the radiotelemetry error associated with the bears' estimated locations, two bears that are in fact together may be estimated to be several hundred metres apart. The median radiotelemetry error for the PBS study site is $261 \mathrm{~m}$, and $95 \%$ of location estimates are within $766 \mathrm{~m}$ of the true location (Zimmerman and Powell 1995). Considering this error, we considered all male and female bears located simultaneously within $600 \mathrm{~m}$ of each other to be a malefemale encounter. Using this criterion, we estimated the number of breeding females encountered by each male and his frequency of encounters with each breeding female during the breeding season (encounter rate). We also documented encounters with nonbreeding females as controls.

\section{Sampling of cubs}

In late February to mid-March, we located the dens of radio-collared females suspected of having bred the previous summer to check for the presence of newborn cubs. We anaesthetized adult females by blowgun or jabstick with Telazol $(250 \mathrm{mg} / \mathrm{mL}$ at a dosage of $1 \mathrm{~mL}$ per female). We removed the 6- to 8-week-old cubs from their dens briefly to collect blood or ear tissue samples, to take measurements, and to mark each for future identification. After the approximately 30-min handling period, cubs were returned to the den and their mother. We were unable to sample the cubs of all radio-collared breeding females because some females dropped their collars after the breeding season and other females had dens that were not feasible to enter (e.g., tree cavities). We sampled seven litters of cubs from five females (two females produced litters in two different years).

\section{Genetic analyses}

We performed microsatellite DNA analysis on the 51 following bears: all 23 trapped males $\geq 2$ years of age, 5 females whose dens we were able to enter in the wintertime and their 22 offspring from seven litters, and 1 cub with an unknown mother who was trapped at 6 months of age. DNA was extracted from blood or ear tissue using Chelex-100 chelating resin (Biorad, Hercules, Calif.) following the protocol of Walsh et al. (1991). DNA was amplified by the polymerase chain reaction (PCR) using primers at the following eight (GT) ${ }_{n}$ microsatellite loci: G1A, G1D, G10B, and G10L (Paetkau and Strobeck 1994) and G10C, G10M, G10P, and G10X (for primer sequences see Paetkau et al. 1995).

PCR was performed in a $25-\mu \mathrm{L}$ cocktail containing $200 \mu \mathrm{M}$ each dNTP, 0.16-0.24 $\mu \mathrm{M}$ each primer (optimized per locus), $1.0-2.5 \mathrm{mM} \mathrm{MgCl}$ (optimized per locus), $0.2 \mathrm{mg}$ $\mathrm{BSA} / \mathrm{mL}, 50 \mathrm{mM} \mathrm{KCl}, 10 \mathrm{mM}$ Tris- $\mathrm{HCl}, 100 \mu \mathrm{g}$ gelatin $/ \mathrm{mL}$, 1 unit of Taq DNA polymerase (Promega, Madison, Wis.), and $15 \mu \mathrm{L}$ of DNA extract ( 100 ng). PCR amplification was performed in a PTC-100 thermal cycler (MJ Research Inc., Waltham, Mass.) using 30 cycles of $30 \mathrm{~s}$ at $94^{\circ} \mathrm{C}, 30 \mathrm{~s}$ at $58^{\circ} \mathrm{C}$, and $1 \mathrm{~min}$ at $72^{\circ} \mathrm{C}$ preceded by $5 \mathrm{~min}$ at $94^{\circ} \mathrm{C}$ and followed by $5 \mathrm{~min}$ at $72^{\circ} \mathrm{C}$. PCR conditions were modified for locus $\mathrm{G} 10 \mathrm{X}$ as follows: $0.27 \mu \mathrm{M}$ each primer, $4 \mathrm{mM}$ $\mathrm{MgCl}_{2}$, and an annealing temperature of $50^{\circ} \mathrm{C}$.

PCR products ranging in size from 100 to 240 base pairs were electrophoresed in 5-7\% native polyacrylamide gels for $15-18 \mathrm{~h}$ at approximately $500 \mathrm{~V}$. Gels were silver-stained following the protocol of Bassam et al. (1991). Conditions were sufficient to achieve the two base-pair resolution needed to distinguish all dinucleotide-repeat alleles. Alleles 
were scored based on their relative sizes (base pairs) using a sample of known genotype and the marker pBR322 (Promega) for size comparisons. For each locus, samples from offspring were run on the same gel as those from their mothers and all putative fathers. Most individuals were genotyped twice to ensure accuracy. Fifty of 51 individuals were genotyped at six to eight loci (35 bears at eight loci, 13 at seven loci, and 2 at six loci). One cub was only genotyped at four loci; owing to the presence of some rare alleles, these four loci were sufficient to establish paternity.

We calculated expected heterozygosities $\left(H_{\mathrm{e}}\right)$ using Nei's (1978) unbiased estimator for small samples and observed heterozygosities $\left(H_{\mathrm{o}}\right)$ for each locus. We used $\chi^{2}$ tests to test for deviations from Hardy-Weinberg equilibrium.

\section{Paternity tests}

Paternity was determined by genetic exclusion by comparing the genotypes of offspring with those of potential fathers. Males who had a genetic mismatch for at least one microsatellite locus were excluded from paternity of that offspring. We calculated paternity exclusion probabilities for each locus $\left(\mathrm{PE}_{1}\right)$ based on the frequency of the paternal allele (pa) using the equation (Chakravarti and Li 1983)

$$
\mathrm{PE}_{1}=(1-\mathrm{pa})^{2}
$$

For the offspring with unknown mother, we used the equation (Chakraborty et al. 1988)

$$
\mathrm{PE}_{1}=(1-a-b)^{2}
$$

where $a$ and $b$ were the frequencies of the offspring alleles. Allele frequencies were calculated from the male-only sample (sensu Morin et al. 1994). We assigned a single multilocus exclusion probability for each offspring by calculating the combined probability of exclusion, $\mathrm{PE}(\mathrm{C})$ (Chakraborty et al. 1988; Chakravarti and Li 1983), whereby

$$
\mathrm{PE}(\mathrm{C})=1-\Pi\left(1-\mathrm{PE}_{1}\right)
$$

\section{Results}

\section{Home ranges}

Home ranges were highly overlapping during the breeding season, as previously documented for black bears in the PBS (see Fig. 1) (the home ranges of all bears are published elsewhere; Powell et al. 1997). Home-range sizes differed significantly among the three size classes of males but were not positively associated with body size ( $p=0.02, n=17$, Kruskal-Wallis test) (Fig. 2a). Medium-sized males had the largest home ranges $\left(47.7 \pm 9.1 \mathrm{~km}^{2}\right.$, mean $\left.\pm \mathrm{SD}\right)$, which were significantly larger than those of small males (29.8 \pm $11.6 \mathrm{~km}^{2}$, Dunn's nonparametric multiple comparisons test, experimentwise $\alpha=0.05$ ). The home-range sizes of large males $\left(39.6 \pm 15.2 \mathrm{~km}^{2}\right)$ did not differ significantly from those of either small or medium-sized males.

\section{Male encounters}

Male encounters with nonbreeding females occurred with a random distribution throughout the breeding season, while those with breeding females were significantly clumped in time ( $p<0.05$, runs test for randomness; Daniel 1990). Male encounter rates were significantly higher with breeding fe-
Fig. 1. Home ranges of three large male black bears, Ursus americanus (a), and one large male (grey line) and five females (b) with whom he bred in one breeding season. Solid line in (a) indicates the boundary of the Pisgah Bear Sanctuary.

(a)

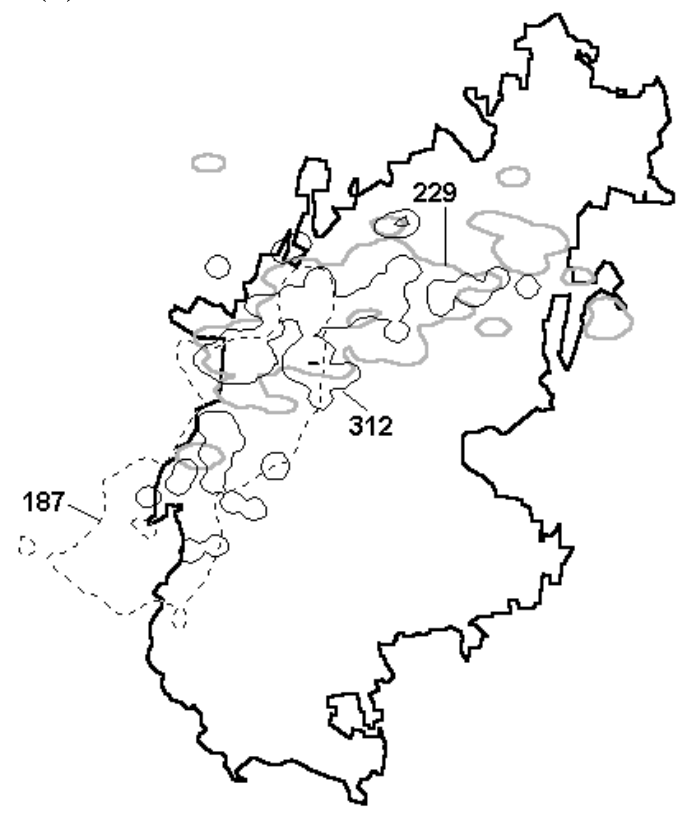

(b)

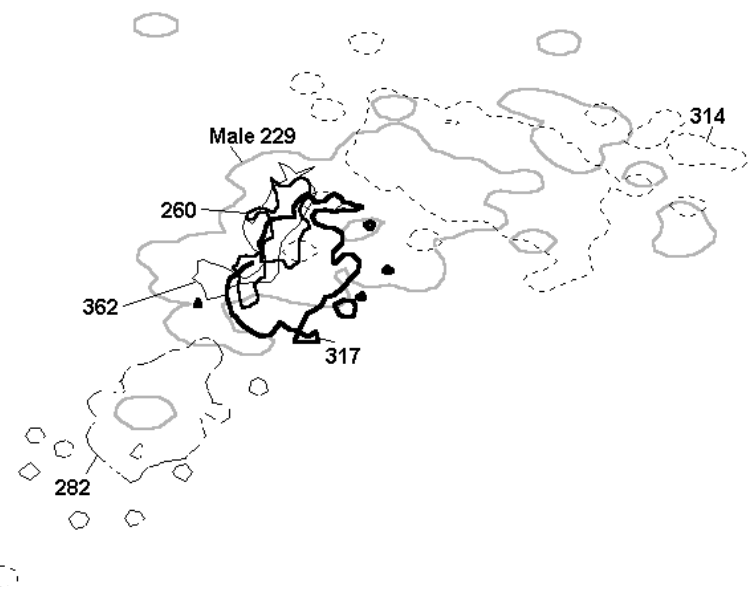

males $(24.7 \pm 10.3$ encounters per female, $n=7$ breeding females; we did not use data from one breeding female whose home range was outside the core of the study area) than with nonbreeding females $(8.8 \pm 4.7$ encounters per female, $n=$ 6 nonbreeding females; $p<0.005, t$ test).

Male encounters with each breeding female were distributed in one (usually) or two clumps of consecutive or nearly consecutive days, preceded and followed by some scattered encounters. We inferred that the clumps of male encounters corresponded to the females' receptive periods, during which multiple males were attempting to gain access, and the scattered encounters resulted from males monitoring female receptivity and leaving the vicinity of unreceptive females. We used behavioural bout analysis (Fagan and Young 1978) to determine the clump boundaries and to estimate each female's receptive period. We found that a "clump" of male 
encounters with a given female was separated from other clumps by at least 4 days on which there were no encounters (Kovach 1998). We used the largest such clump of male encounters as the estimated receptive period. We identified one distinct clump of 3-12 days in length for each of seven breeding females (one of these females was in breeding condition in two consecutive years) and two distinct clumps of 5-6 days each, separated by 30 days, for one additional breeding female. We assumed that this female had two receptive periods (Eiler et al. (1989) reported that oestrus in black bears can be cyclic or recurrent). We compared the patterns of encounters that occurred during the estimated receptive periods and the entire breeding season for males of the three size categories.

Three to nine males encountered each breeding female on at least 1 day of the breeding season, and one to seven males encountered each breeding female on at least 1 day of her estimated receptive period. The radiotelemetry data indicated that some males came and left the vicinity of a breeding female repeatedly during her estimated receptive period, while others stayed for a prolonged period lasting from 2 to 6 days. Males encountered zero to five radio-collared breeding females (mean $=2.7$ ) during the breeding season.

Males of the three size categories differed significantly in the number of females encountered during the breeding season ( $p=0.03$, Kruskal-Wallis) (Fig. 2b). Large males encountered significantly more females $(4.6 \pm 0.5$ females $)$ than did medium-sized $(2.2 \pm 1.9)$ and small males $(2.1 \pm$ 1.6). Males of the three size classes did not differ in their frequency of encounters per female throughout the entire breeding season $(3.3 \pm 1.4$ encounters per female for all males) but differed significantly in their frequency of encounters during the females' estimated receptive periods ( $p=$ 0.036, Kruskal-Wallis) (Fig. 2c). Large males had significantly more encounters during the estimated receptive periods $(1.7 \pm 1.1$ encounters $)$ than did small males $(0.3 \pm 0.60)$ (Dunn's experimentwise $\alpha=0.10$ ). The encounters of medium-sized males $(0.67 \pm 0.7)$ did not differ significantly from either. The difference in the encounter rates of largeand medium-sized males during the estimated receptive periods, although not statistically significant, may indicate a trend with biological significance.

\section{Paternity analysis}

The microsatellite loci were highly polymorphic in the study population, with 4-7 alleles per locus and 44 alleles for the eight loci combined (Table 1). Heterozygosities were in the $60-80 \%$ range for six of the eight loci and 40 and $95 \%$ for the other two loci, respectively. No loci deviated significantly from Hardy-Weinberg expectations.

We performed a total of 505 paternity exclusions for the 23 offspring. The mean number of loci used to exclude a male from paternity was 3.6. All paternal genotypes of the offspring could be traced to at least one sampled male. Multiple paternity occurred in two of seven litters. Both of the multiply fathered litters were litters of four offspring, and one of them had three fathers.

For 22 of 23 offspring, all but one male were excluded from paternity. The $\mathrm{PE}(\mathrm{C}) \mathrm{s}$ ranged from 0.977 to 0.999 (Table 2). For one offspring (No. 310), two males (Nos. 219 and 229) could not be excluded. This analysis was based on six
Fig. 2. Mean home-range size of black bears $(a)$, mean number of breeding females encountered during the breeding season $(b)$, and mean frequency of encounters per breeding female during the breeding season (solid bars) and during the estimated receptive periods (stippled bars) for the three size classes of males $(c)$. Different letters above the bars indicate a statistically significant difference.

(a)

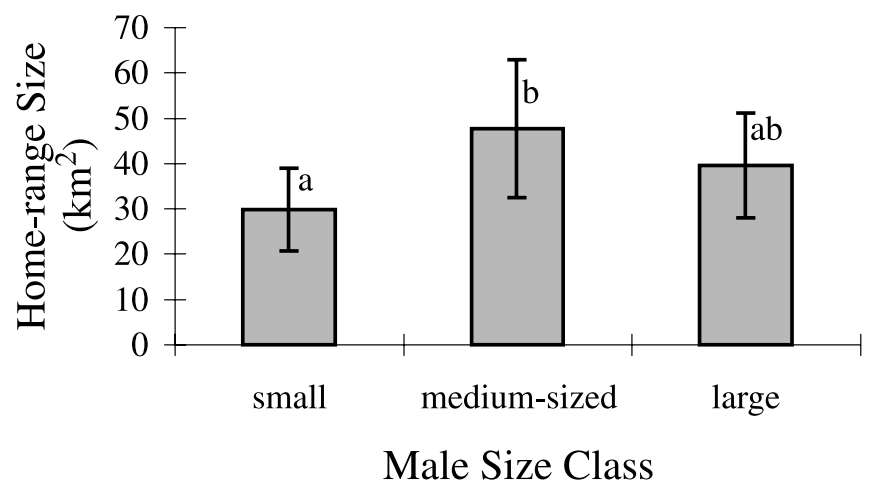

(b)

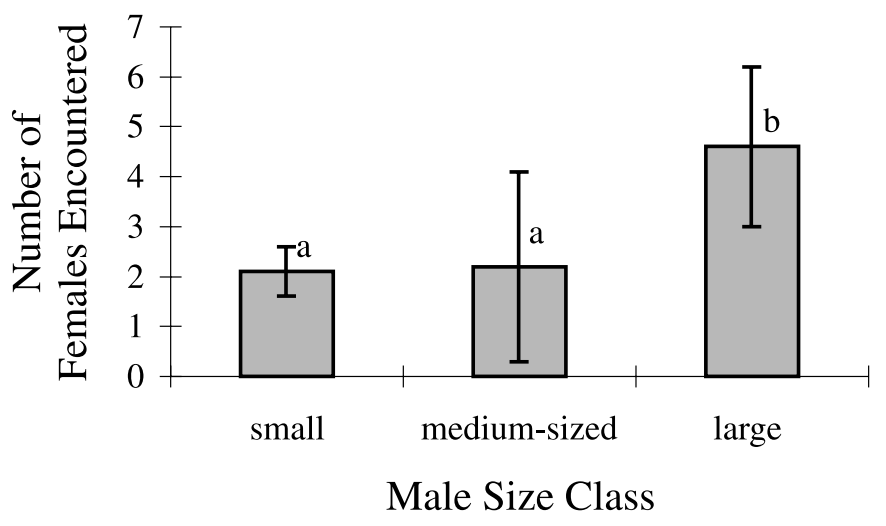

(c)

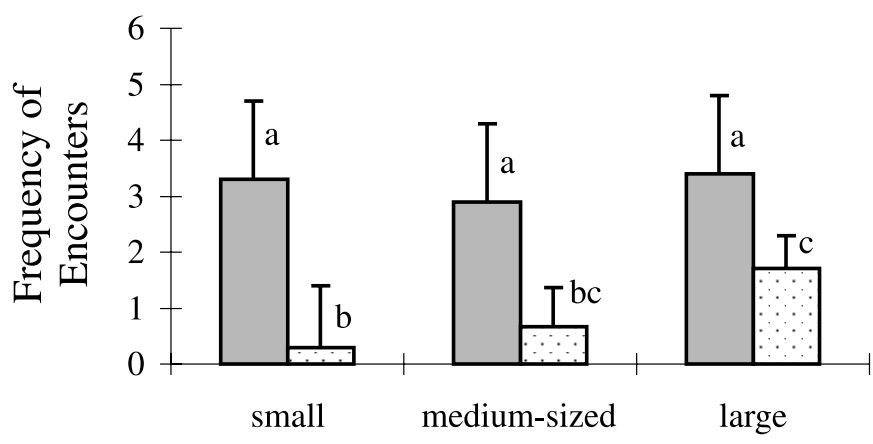

Male Size Class

loci and yielded the lowest $\mathrm{PE}(\mathrm{C})$ in this study (0.954). Because paternity could not be resolved, this cub was omitted from further analyses.

Five males fathered 22 cubs in the following proportions: three large males fathered four $(18 \%)$, eight $(36 \%)$, and 
eight of the offsprings, respectively. One medium-sized and one small male each fathered one $(4.5 \%)$ offspring. Large males fathered significantly more offspring than small and medium-sized males (20 of 22 offspring, 91\%; $p<0.005, \chi^{2}$ test) (Fig. 3). All three (100\%) resident large males reproduced successfully, and 2 of 19 (10.5\%) medium-sized and small males reproduced successfully. During the 3-year study, $23 \%$ of the resident males (5 of 22) reproduced successfully and $14 \%$ of them ( 3 of 22 ) fathered $91 \%$ of the offspring.

\section{Association between paternity and encounter rates}

Data on both male encounters and paternity were available for four litters belonging to four different females, enabling us to compare the results of the two different data sets (Table 2) (for the other three litters sampled, only paternity data were available, and no comparisons could be made between encounters and paternity). For three of these four females, we found a correspondence between male encounter rates and paternity. The males with the most frequent encounters with a given female during her estimated receptive period were also the males that fathered part or all of her subsequent litter. For the fourth female (No. 362), male encounter rates did not explain paternity. The male who fathered her litter (male No. 312) was one of eight males who encountered female 362 throughout the breeding season. Six other males had more frequent encounters with female 362 than did male 312. Encounter-rate data for female 362 may have been incomplete because she was not radio-collared for the first third of the breeding season. Numerous males, however, had frequent encounters with female 362 during the time she was radio-collared suggesting that she was radiocollared during her receptive period.

\section{Discussion}

\section{Male tactics}

In this study, we found that body size influenced male behaviour during the breeding season. Although male homerange sizes were not positively associated with body size, male encounter rates with breeding females were. Contrary to our predictions, small and medium-sized males had breeding season home ranges no smaller than those of large males, indicating that all males searched widely for receptive females. Because of their competitive disadvantage, small and medium-sized males were expected to use smaller ranges to improve their chances of mating successfully with at least one closely monitored female. Our findings suggest that the competitively inferior males widened their home ranges to increase their chances of encountering unguarded females and that close monitoring of females is not a successful tactic for these males, as most receptive females are located and guarded by large males. Having a large home range may increase a small male's chance of gaining matings with uncontested females when he stands no chance of gaining matings by displacing competing males (Madsen et al. 1993; Fisher and Lara 1999). In addition, the large homerange sizes of small and medium-sized male bears in our study may have resulted from their increased movements to avoid large males that frequently roamed through their home
Table 1. Polymorphism of black bears, Ursus americanus, at the Pisgah Bear Sanctuary at the eight microsatellite loci used.

\begin{tabular}{lllll}
\hline & & & \multicolumn{2}{l}{ Heterozygosity } \\
\cline { 3 - 5 } Locus & $\begin{array}{l}\text { No. of } \\
\text { alleles }\end{array}$ & $\begin{array}{l}\text { Most frequent } \\
\text { allele }\end{array}$ & $H_{\mathrm{o}}$ & $H_{\mathrm{e}}$ \\
\hline G1A & 6 & 0.435 & 0.710 & 0.752 \\
G10B & 5 & 0.452 & 0.677 & 0.646 \\
G10C & 6 & 0.525 & 0.645 & 0.646 \\
G1D & 4 & 0.433 & 0.567 & 0.664 \\
G10H & 4 & 0.435 & 0.645 & 0.672 \\
G10L & 7 & 0.31 & 0.931 & 0.818 \\
G10P & 8 & 0.379 & 0.862 & 0.802 \\
G10X & 4 & 0.45 & 0.400 & 0.625 \\
Total & 44 & & 0.680 & 0.703 \\
\hline
\end{tabular}

ranges (Jonkel and Cowan 1971; Young and Ruff 1982; Garshelis and Hellgren 1994).

In accordance with our hypothesis, male encounters with breeding females were a function of body size. Large males encountered, on average, twice as many breeding females as did small and medium-sized males. Males also differed in the timing of their encounters with breeding females. Although all males encountered breeding females with similar frequency throughout the entire breeding season, large males had more encounters than small males during the females' estimated receptive periods.

We inferred male mating access from the data on male encounters with breeding females. The distribution of encounters with breeding and nonbreeding females indicates that male encounters with breeding females cannot be attributed to coincidence. Furthermore, adult male and female black bears do not associate except to mate (Rogers 1987), nor did bears in our study area aggregate at common feeding sources (Powell et al. 1997). Males' infrequent and random encounters with nonbreeding females were likely a result of males briefly entering these females' home ranges and, possibly, checking their reproductive conditions, or they may have been a result of radiotelemetry error. In contrast, the frequent and clumped nature of males' encounters with breeding females likely resulted from males attempting to gain mating access to these females while they were in oestrus. In other black bear populations, Barber and Lindzey (1986) and Rogers (1987) observed males associating with breeding females in exactly the pattern that we deduced from our radiotelemetry data.

The differences in encounter rates that we found among different-sized male bears suggest that, despite using similar search tactics, they did not have equal access to receptive females. Large males monitored several breeding females and focused their encounters during the females' estimated receptive periods. Their competitive advantage appeared to enable them, like the competitively superior or dominant males in many polygynous species, to monopolize access to females during their peak receptive periods (Hausfater 1975; Dewsbury 1984; Huck et al. 1986). Due to the asynchronous oestrus of females, large males were able to gain access to multiple, receptive females, sequentially, throughout the 3month breeding season. In contrast, small males appeared to have very limited access to receptive females. Although they had numerous encounters with breeding females, the major- 
Table 2. Male black bear encounters with breeding females and paternity of offspring sampled in the Pisgah Bear Sanctuary.

\begin{tabular}{|c|c|c|c|c|c|c|}
\hline $\begin{array}{l}\text { Mother's } \\
\text { ID No. }\end{array}$ & $\begin{array}{l}\text { Offspring } \\
\text { birth year }\end{array}$ & $\begin{array}{l}\text { Offspring's } \\
\text { ID No. }\end{array}$ & $\begin{array}{l}\text { Father's ID } \\
\text { No. and size } \\
\text { class* }\end{array}$ & $\begin{array}{l}\text { Paternity } \\
\text { exclusion } \\
\text { probability (PE) }\end{array}$ & $\begin{array}{l}\text { ID No. and size class of males } \\
\text { with encounters during the } \\
\text { breeding season* }\end{array}$ & $\begin{array}{l}\text { ID No. and size class of } \\
\text { male with most frequent } \\
\text { encounters during the } \\
\text { receptive period* }\end{array}$ \\
\hline \multirow[t]{5}{*}{260} & 1994 & 312 & $312-\mathrm{L}$ & 0.999 & No radiotelemetry data & \\
\hline & & 313 & $312-\mathrm{L}$ & 0.999 & & \\
\hline & & 314 & $312-\mathrm{L}$ & 0.999 & & \\
\hline & & 385 & $187-\mathrm{L}$ & 0.999 & & \\
\hline & & 386 & $187-\mathrm{L}$ & 0.999 & & \\
\hline \multirow[t]{3}{*}{274} & 1994 & 309 & $229-\mathrm{L}$ & 0.993 & No radiotelemetry data & \\
\hline & & 310 & 229-L, 219-M ${ }^{\dagger}$ & 0.954 & & \\
\hline & & 311 & $229-\mathrm{L}$ & 0.992 & & \\
\hline \multirow[t]{4}{*}{266} & 1994 & 306 & $229-\mathrm{L}$ & 0.997 & No radiotelemetry data & \\
\hline & & 347 & $312-\mathrm{L}$ & 0.999 & & \\
\hline & & 348 & $229-\mathrm{L}$ & 0.983 & & \\
\hline & & 349 & $312-\mathrm{L}$ & 0.998 & & \\
\hline \multirow[t]{4}{*}{278} & 1995 & 342 & 229-L & 0.991 & 229-L, 329-S, 312-L & 229-L \\
\hline & & 343 & $229-\mathrm{L}$ & 0.981 & & \\
\hline & & 344 & 226-M & 0.992 & & \\
\hline & & 345 & $256-\mathrm{S}$ & 0.998 & & \\
\hline \multirow[t]{2}{*}{362} & 1996 & 387 & $312-\mathrm{L}$ & 0.999 & $\begin{array}{l}\text { 352-M, 229-L, 368-M, 187-L, } \\
\text { 312-L, 245-M, 226-M, 323-S }\end{array}$ & $352-\mathrm{M}=229-\mathrm{L}=368-\mathrm{M}^{\ddagger}$ \\
\hline & & 388 & $312-\mathrm{L}$ & 0.989 & & \\
\hline 272 & 1995 & 358 & $187-\mathrm{L}$ & 0.998 & No radiotelemetry data & \\
\hline
\end{tabular}

Fig. 3. Proportion of offspring sired by the three size classes of male black bears.

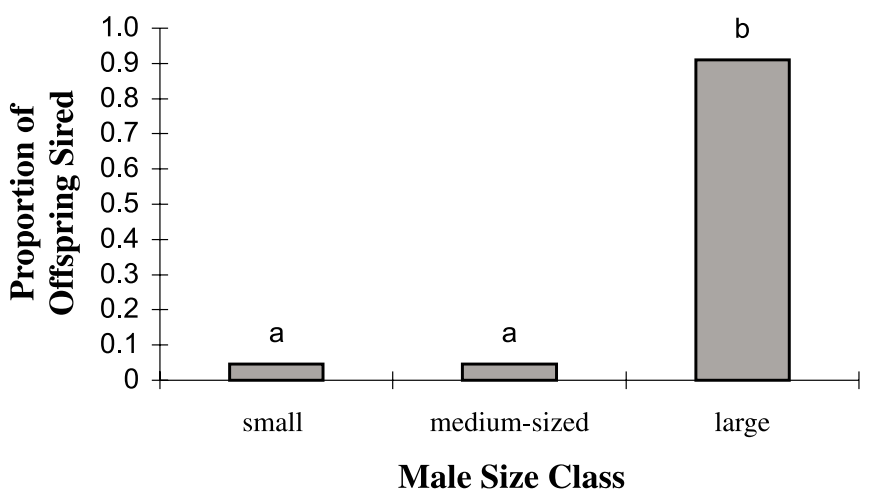

ity of them occurred outside of the females' estimated receptive periods. Medium-sized male bears varied in their encounter rates with receptive females. Some medium-sized males had frequent encounters with one or two females during their estimated receptive periods, while others had few or no encounters during the receptive period of any female. These behavioural differences may have resulted from differences in the size, age, or experience of these males (Dunbar et al. 1990).
Male competition for mates in our study appeared to be intense. Numerous males encountered each breeding female. Males often came and left the vicinity of a breeding female repeatedly during her receptive period, while others stayed with the same female for several days, suggesting that some males were displaced by others. For example, during one period of radiotelemetry data collection, two large males (Nos. 229 and 312) were both within $200 \mathrm{~m}$ of female 266. Forty minutes later, male 312 was located $4 \mathrm{~km}$ away, while male 229 remained in close proximity to female 266 and they moved together into a cove. Male 312 was not located near female 266 during the next several days.

Most of our findings are consistent with previous reports of black bear mating behaviour, including the occurrence of roaming male tactics and both male and female promiscuity (Barber and Lindzey 1986; Rogers 1987; Schenk and Kovacs 1995). Our results, however, do not support the suggestion that black bears are serially monogamous (Schenk and Kovacs 1995), as both sexes mated with multiple partners over a short period of time, and prolonged male-female associations were not usually observed. We also found no evidence of a stable dominance hierarchy among males as suggested by Barber and Lindzey (1986). Instead, different, large (or sometimes medium-sized) males monopolized encounters with different females. In addition, males trapped in the breeding season often had wounds, new scars, and bro- 
ken canines; an indication that they had been fighting. We conclude, therefore, that male black bears in our study area pursue multiple receptive females, sequentially, and fight for access to each female encountered. Our findings are similar to those for other solitary species, such as the opossum, Didelphis virginiana (Ryser 1992), and bridled nailtail wallaby, Onychogalea fraenata (Fisher and Lara 1999), and support the hypothesis that established dominance hierarchies are not adaptive in solitary species (Gosling 1986; Fisher and Lara 1999).

Our finding of multiple paternity in two of seven litters highlights the importance of sperm competition in black bear mating behaviour (Schenk and Kovacs 1995). Black bears are induced ovulators (Whimsatt 1963), implying that the first male to mate will trigger ovulation and thereby have an advantage in fertilization (Foltz and Schwagmeyer 1989). As a result, selection will be strong on males to be the first to locate oestrous females and long-term postcopulatory guarding will not be favoured. Males must constantly evaluate the reproductive condition of several females and decide how to invest in reproductive effort (Schwagmeyer 1995). If multiple males are likely to locate each receptive female, males with superior fighting abilities might benefit from limited guarding of females that are approaching the onset of oestrus. The few short-term male-female associations that we observed in this study may have resulted from males engaging in such precopulatory guarding.

Although our study focused on the behaviour of males, we recognize that females are not passive bystanders in the male competitive arena, and they may have an important role in determining male mating success. Females may encourage promiscuous mating because it promotes sperm competition and thereby provides many potential benefits (e.g., increased probability of fertilization, infanticide avoidance, and enhanced genetic quality of offspring; reviewed in Andersson 1994; Gomendio et al. 1998). Future research on black bear mating behaviour should address the role of female behaviours, including the possible role of female mate choice.

\section{Male reproductive success}

Paternity was highly skewed towards the three largest and oldest males in the population, who fathered $91 \%$ of the offspring, during the 3-year study. Paternity has been positively correlated with body size in many polygynous mammals, and high reproductive skew is characteristic of the most sexually dimorphic species (Wickings et al. 1993; Hoelzel et al. 1999; Garnier et al. 2001; McElligott et al. 2001). Strong selective pressures in these species maintain sexual dimorphism by favouring traits that confer male reproductive success (McElligott et al. 2001; Webster et al. 2001). In black bears, sexual selection appears to maintain sexual size dimorphism because large size confers male reproductive success.

Studies of paternity in solitary carnivores are limited to date. Schenk and Kovacs (1995) documented dual paternity of black bear litters and suggested a correlation between body size and male reproductive success. In the grizzly bear (Ursus arctos) paternity is biased towards large and old males but is distributed relatively evenly among several successful males (Craighead et al. 1995; Cronin et al. 1999). In Craighead et al.'s (1995) study, no single male fathered more than $13 \%$ of the offspring compared with $36 \%$ for the most successful males in this study. Reproductive success in cougars, Puma concolor, is also biased toward a subset of adult males (37 and $47 \%$ in two different populations; Logan et al. 1996; Murphy 1998), and the two most successful males sired 14 of 23 litters in one population. In large solitary carnivore populations, therefore, a certain subset of experienced (old and large) males contributes disproportionately to the production of offspring. Our short-term data indicate that in black bears, a smaller proportion of males breed successfully than in grizzly bear and cougar populations. One explanation is that the wider ranging habits of grizzlies and cougars limit the number of females that an individual male can monopolize (males and females of both species may have home ranges in the hundreds of square kilometres). The high reproductive skew that we observed in this study also contrasts with findings from another solitary species, the bridled nailtail wallaby (Fisher and Lara 1999), but is similar to findings for the solitary black rhinoceros, Diceros bicornis (Garnier et al. 2001).

In solitary species, variance in male reproductive success is expected to be lower than in social species because female dispersion makes it more difficult for one male to monopolize access to females (Emlen and Oring 1977; CluttonBrock 1989). In addition, search ability might be important in mating success, and it might not be correlated with body size, thus increasing the potential for a greater number of males to breed successfully (Schwagmeyer and Woontner 1986; Fisher and Lara 1999). If, however, despite female dispersion, males have the potential to locate multiple females, and several males locate each female simultaneously, then fighting ability is the most important factor determining male success (Schwagmeyer 1988; Madsen et al. 1993). Our results suggest that the latter scenario, combined with the pronounced size differences among males, results in high reproductive skew in black bears.

In this study, we measured short-term reproductive success over a 3-year period. Although short-term data are valuable to study mating systems and to identify traits that are influenced by sexual selection, selective pressures act on an individual's reproductive output over its lifetime (Coltman et al. 1998). Lifetime reproductive success is a function of an individual's short-term (seasonal) production of offspring and its reproductive tenure (Altmann et al. 1996). The longterm data needed to document reproductive tenure, however, are difficult to collect for long-lived organisms with long reproductive life spans, such as black bears. Long-term data for some polygynous mammals have shown that the duration of male reproductive tenure varies among species, even within the same taxa. For example, dominance status is unstable and reproductive tenure short-lived in some pinnipeds and primates (Altmann et al. 1996; Pope 1996; Coltman et al. 1998). High variance in short-term reproductive success in these species does not translate into the long term. In contrast, reproductive tenure is long-lasting in other species of pinnipeds and some ungulates with skewed, seasonal mating success (Arnould and Duck 1997; Wilmer et al. 1999; Wilson et al. 2002).

Data on reproductive tenure of black bears, unfortunately, are unavailable to estimate lifetime reproductive success and its variance among males within a population. Our findings, 
however, enable us to make some predictions. We expect that male reproductive success over the long term will not be as skewed as during our short-term study, but we also do not expect it to be homogenized by high turnover among males. We predict that variance in male reproductive success will be maintained over the long term because large males will maintain their reproductive dominance for several consecutive seasons. Similar predictions have been made for polygynous ungulates: short-term variance in male reproductive success should be maintained over the long term when mating success depends on fighting ability and male mortality is high (Clutton-Brock 1988; Moore et al. 1995). These conditions apply to black bears. Males are not successful breeders until they have grown to a threshold in body size $(\sim 135 \mathrm{~kg}$ in this study), but once they achieve this size, they have a major competitive advantage owing to their superior fighting ability. Reproductively successful males should maintain this competitive edge in subsequent years as they continue to grow and enhance their fighting abilities (as in the fur seal, Arctocephalus gazella; Arnould and Duck 1997) until they reach a peak age, after which their reproduction declines (Clutton-Brock 1988; Poole 1989). In our study area, less than $20 \%$ of male bears survive to age 6 (Sorensen and Powell 1998), the minimum age at which they attain the $135-\mathrm{kg}$ threshold. Of those bears that survive to age 6 , not all will breed successfully owing to individual variation in the sizes of same-aged males (not all 6-year-old males weighed $>135 \mathrm{~kg}$ ). Therefore, significantly less than $20 \%$ of all males in the PBS population will reproduce successfully, which is consistent with the short-term findings of this study.

It is important to note that our study population was largely free of hunting pressures owing to its protection as a bear sanctuary (although males with home ranges that exceeded the sanctuary boundaries were occasionally hunted). Male reproductive behaviour may differ in a more heavily hunted population as a result of changes in its demographic structure. Studies of large carnivores have shown that hunting reduces reproductive life spans and generates high turnover among breeding males (Harris and Allendorf 1989; Murphy et al. 1999). Hunter preferences for large animals may result in the removal of the experienced breeders from the population and may result in a more even distribution of reproduction among males. Although this factor may increase the genetically effective population size, it may also disrupt behavioural adaptations and social organization that have evolved over thousands of years (Murphy et al. 1999; Harris et al. 2002). The selective hunting of large male bears, for example, generates an influx of young, potentially infanticidal immigrant males, which may reduce the reproductive success of adult females (Wielgus and Bunnell 2000). Hunting pressure that changes the natural mortality patterns, therefore, may have long-term evolutionary consequences (Murphy et al. 1999; Harris et al. 2002).

\section{Correlation of mating success and reproductive success}

Numerous studies using genetic paternity determination have shown that behavioural estimates of mating success are unreliable predictors of reproductive success (e.g., Westneat et al. 1990; Harris et al. 1991; Travis et al. 1996; Hoelzel et al. 1999). In this study, for three of the four females for whom we had data on both male encounters and paternity, the males that had the most frequent encounters during the estimated receptive periods were the same males to whom we assigned paternity for at least a portion of the litter. For the fourth female (No. 362), male encounter rates were not correlated with paternity. The reason for this discrepancy is not clear, and this result indicates either an important exception or a shortcoming of our radiotelemetry data. In light of the small sample of females for whom we were able to obtain data on both male encounters and paternity, additional studies are needed to evaluate the relationship between male mating success and reproductive success.

Encounter rates with estimated receptive females corresponded well with paternity, in general, for the large and small male categories. Large males had high encounter rates and high reproductive success. Small males had few or no encounters during females' estimated receptive periods and low reproductive success. For medium-sized males, however, encounter rates overestimated male reproductive success. Some medium-sized males had frequent encounters with one or a few receptive females, but only one medium-sized male fathered one offspring. Encounter rates, therefore, would have predicted the general pattern of large male success but would have attributed success to more males, including some medium-sized males. Similarly, Pemberton et al. (1992) found that behavioural estimates of mating success in red deer, Cervus elaphus, provided an accurate estimate of the relative reproductive success among males but underestimated the variance in true male reproductive success.

\section{Conclusion}

In conclusion, we have shown that short-term reproductive success in male black bears is strongly influenced by body size and skewed towards the largest males in the population. The high variance in male reproduction that we found in this study is unexpected for solitary species and is greater than that predicted by the environmental potential for polygyny. We attribute this to the highly mobile search tactics and superior fighting ability of large males, which enable them to monitor numerous females within their home ranges and prevent smaller males from gaining mating access through alternative tactics. We predict that the bias in reproduction that we observed over the short term will be manifest in the lifetime reproductive success of males, although to a lesser degree. Further research on the reproductive tenure of males is needed to test this prediction. Furthermore, because carnivores show tremendous behavioural plasticity in response to environmental variation across their ranges, similar studies of other black bear populations should be conducted before species-wide generalizations are made. Studies of paternity and mating behaviour in solitary carnivore species are still sorely lacking, despite their theoretical and practical (management and conservation) importance.

\section{Acknowledgements}

Funding was provided by the Geraldine R. Dodge Foundation, Earthwatch Institute/The Center for Field Research, the International Association for Bear Research and Management, the National Rifle Association, the Max McGraw Wildlife Foundation, the American Museum Theodore Roosevelt Fund, the Grand Valley State University McNair 
Scholars Program, the North Carolina Agricultural Research Service, North Carolina State University (NCSU), the WilBurt Corp., and a NCSU-GAANN Fellowship. In addition, generous private contributions were given by Bob Bacon, Dick and Ginger King, and Jim Hott. Critical logistic support was provided by the National Park Service, the USDA Forest Service, and the North Carolina Agricultural Research Service, NCSU. The NCSU Crop Sciences Molecular Markers Laboratory, Terence Bradley, and Bob Chapman provided assistance, equipment, and space for the laboratory work. David Paetkau and Curtis Strobeck provided microsatellite primers and initial PCR protocols. Field assistance was provided by Mike Mitchell, Vanessa Sorensen, FaithRenee Foster, and numerous undergraduate interns and Earthwatch volunteers. Porte Clyde and Stinson canning companies provided sardines. Bill King, David Berlinsky, and Marian Litvaitis read earlier drafts of this manuscript. Editorial suggestions by Michelle P. Scott, David Westneat, E. Charles Meslow, and two anonymous reviewers greatly improved the manuscript.

\section{References}

Altmann, J., Alberts, S.C., and Haines, S.A. et al. 1996. Behavior predicts genetic structure in a wild primate group. Proc. Natl. Acad. Sci. U.S.A. 93: 5797-5801.

Andersson, M. 1994. Sexual selection. Princeton University Press, Princeton, N.J.

Arnould, J.P.Y., and Duck, C.D. 1997. The cost and benefits of territorial tenure, and factors affecting mating success in male Antarctic fur seals. J. Zool. (Lond.), 241: 649-664.

Barber, K.R., and Lindzey, F.G. 1986. Breeding behaviour of black bears. In Bears - Their Biology and Management: Proceedings of the Sixth International Conference on Bear Research and Management, Grand Canyon, Ariz., 18-22 February 1983. Edited by P. Zager. International Association for Bear Research and Management. pp. 129-136. [Available from Michael R. Pelton, Department of Forestry, Wildlife, and Fisheries, The University of Tennessee, P.O. Box 1071, Knoxville, TN 379011071, U.S.A.]

Bassam, B.J., Caetano-Anolles, G., and Gresshoff, P.M. 1991. Fast and sensitive silver staining of DNA in polyacrylamide gels. Anal. Biochem. 196: 80-83.

Bunnell, F.L., and Tait, D.E.N. 1981. Population dynamics of bears - implications. In Dynamics of large mammal populations. Edited by C.W. Fowler and T.D. Smith. John Wiley \& Sons, Inc., New York. pp. 75-98.

Chakraborty, R., Meagher, T.R., and Smouse, P.E. 1988. Parentage analysis with genetic markers in natural populations. I. The expected proportion of offspring with unambiguous paternity. Genetics, 118: 527-536.

Chakravarti, A., and Li, C.C. 1983. The effect of linkage on paternity calculations. In Inclusion probabilities in parentage testing. Edited by R.H. Walker, R.J. Duquesnoy, E.R. Jennings, et al. American Association of Blood Banks, Arlington, Va. pp. 411420.

Clutton-Brock, T.H. 1988. Reproductive success. University of Chicago Press, Chicago.

Clutton-Brock, T.H. 1989. Mammalian mating systems. Proc. R. Soc. Lond. B Biol. Sci. 236: 339-372.

Coltman, D.W., Bowen, W.D., and Wright, J.M. 1998. Male mating success in an aquatically mating pinniped, the harbour seal
(Phoca vitulina), determined by microsatellite DNA markers. Mol. Ecol. 7: 627-638.

Coltman, D.W., Bowen, W.D., and Wright, J.M. 1999. Male reproductive success in a promiscuous mammal: behavioural estimates compared with genetic paternity. Mol. Ecol. 8: 11991209.

Cook, B. 1984. Chemical immobilization of black bears in Great Smoky Mountains National Park. In Proceedings of the Seventh Eastern Workshop on Black Bear Research and Management, Homosassa Springs, Fla., 26-29 March 1984. pp. 79-81. [Available from Michael R. Pelton, Department of Forestry, Wildlife, and Fisheries, The University of Tennessee, P.O. Box 1071, Knoxville, TN 37901-1071, U.S.A.]

Craighead, L., Paetkau, D., Reynolds, H.V., Vyse, E.R., and Strobeck, C. 1995. Microsatellite analysis of paternity and reproduction in arctic grizzly bears. J. Hered. 86: 255-261.

Cronin, M., Shideler, R., Hechtel, J., Strobeck, C., and Paetkau, D. 1999. Genetic relationships of grizzly bears (Ursus arctos) in the Prudhoe Bay region of Alaska: inference from microsatellite DNA, mitochondrial DNA, and field observations. J. Hered. 90: 622-628.

Daniel, W.W. 1990. Applied nonparametric statistics. PWS-KENT Publishing Co., Boston, Mass.

Darwin, C. 1871. The descent of man, and selection in relation to sex. John Murray, London, U.K.

Dewsbury, D.A. 1982. Dominance rank, copulatory behaviour, and differential reproduction. Q. Rev. Biol. 57: 135-159.

Dewsbury, D.A. 1984. Sperm competition in muroid rodents. In Sperm competition and the evolution of animal mating systems. Edited by R.L. Smith. Academic Press Inc., Orlando, Fla. pp. 547-571.

Dominey, W.J. 1984. Alternative mating tactics and evolutionarily stable strategies. Am. Zool. 24: 385-396.

Dunbar, R.I.M., Buckland, D., and Miller, D. 1990. Mating strategies of male feral goats: a problem in optimal foraging. Anim. Behav. 40: 653-667.

Eiler, J.H., Wathen, G.W., and Pelton, M.R. 1989. Reproduction in black bears in the southern Appalachian mountains. J. Wildl. Manag. 53: 353-360.

Ellis, L. 1995. Dominance and reproductive success among nonhuman animals: a cross-specific comparison. Ethol. Sociobiol. 16: 257-333.

Emlen, S.T., and Oring, L.W. 1977. Ecology, sexual selection, and the evolution of mating systems. Science (Wash., D.C.), 197: 215-223.

Engh, A.L., Funk, S.M., Van-Horn, R.C., Scribner, K.T., Bruford, M.W., Libants, S., Szykman, M., Smale, L., and Holekamp, K.E. 2002. Reproductive skew among males in a female-dominated mammalian society. Behav. Ecol. 13: 193-200.

Fagan, R.M., and Young, D.Y. 1978. Temporal patterns of behaviors: durations, intervals, latencies, and sequences. In Quantitative ecology. Edited by P.W. Colgan. John Wiley \& Sons, Inc., New York. pp. 79-114.

Fisher, D.O., and Lara, M.C. 1999. Effects of body size and home range on access to mates and paternity in male bridled nailtail wallabies. Anim. Behav. 58: 121-130.

Foltz, D.W., and Schwagmeyer, P.L. 1989. Sperm competition in the 13-lined ground squirrel: differential fertilization success under field conditions. Am. Nat. 133: 257-265.

Frank, L.G. 1986. Social organisation of the spotted hyena (Crocuta crocuta). II. Dominance and reproduction. Anim. Behav. 35: 1510-1527. 
Garnier, J.N., Bruford, M.W., and Goossens, B. 2001. Mating system and reproductive skew in the black rhinoceros. Mol. Ecol. 10: 2031-2041.

Garshelis, D.L., and Hellgren, E.C. 1994. Variation in reproductive biology of black bears. J. Mammal. 75: 175-188.

Gemmell, N.J., Burg, T.M., Boyd, I.L., and Amos, W. 2001. Low reproductive success in territorial male Antarctic fur seals (Arctocephalus gazella) suggests the existence of alternative mating strategies. Mol. Ecol. 10: 451-460.

Gomendio, M., Harcourt, A.H., and Roldan, E.R.S. 1998. Sperm competition in mammals. In Sperm competition and sexual selection. Edited by T.R. Birkhead and A.P. Møller. Academic Press, London, U.K. pp. 667-751.

Gosling, L.M. 1986. The evolution of mating strategies in male antelopes. In Ecological aspects of social evolution. Edited by D.I. Rubenstein and R.W. Wrangham. Princeton University Press, Princeton, N.J. pp. 244-281.

Gross, M.R. 1996. Alternative reproductive strategies and tactics: diversity within sexes. Trends Ecol. Evol. 11: 92-97.

Harris, A.S., Young, J.S.F., and Wright, J.M. 1991. DNA fingerprinting of harbour seals (Phoca vitulina concolor): male mating behaviour may not be a reliable indicator of reproductive success. Can. J. Zool. 69: 1862-1866.

Harris, R.B., and Allendorf, F.W. 1989. Genetically effective population size of large mammals: an assessment of estimators. Conserv. Biol. 3: 181-191.

Harris, R.B., Wall, W.A., and Allendorf, F.W. 2002. Genetic consequences of hunting: what do we know and what should we do? Wildl. Soc. Bull. 30: 634-643.

Hausfater, G. 1975. Dominance and reproduction in baboons (Papio cynocephalus): a quantitative analysis. Contrib. Primatol. 7: 1-150.

Hoelzel, A.R., Le Boeuf, B.J., Reiter, J., and Campagna, C. 1999. Alpha-male paternity in elephant seals. Behav. Ecol. Sociobiol. 46: $298-306$.

Huck, U.W., Lisk, R.D., Allison, J.C., and Van Dongen, C.C. 1986. Determinants of mating success in the golden hamster (Mesocricetus auratus): social dominance and mating tactics under seminatural conditions. Anim. Behav. 34: 971-989.

Johnson, K.G., and Pelton, M.R. 1980. Prebaiting and snaring techniques for black bears. Wildl. Soc. Bull. 8: 46-54.

Jonkel, C.J., and Cowan, I. McT. 1971. The black bear in the spruce-fir forest. Wildl. Monogr. No. 27. pp. 1-57.

Kovach, A. 1998. Dominance and reproduction in male black bears. Ph.D. thesis, North Carolina State University, Raleigh.

LeCount, A.L. 1982. Characteristics of a central Arizona black bear population. J. Wildl. Manag. 46: 861-868.

Logan, K.A., Sweanor, L.L., Ruth, T.K., and Hornocker, M.G. 1996. Cougars of the San Andres Mountains, New Mexico. Final report, project W-128-R, New Mexico Department of Game and Fish, Santa Fe.

Madsen, T., Shine, R., Loman, J., and Hakansson, T. 1993. Determinants of mating success in male adders, Vipera berus. Anim. Behav. 45: 491-99.

McElligott, A.G., Gammell, M.P., Harty, H.C., Paini, D.R., Murphy, D.T., Walsh, J.T., and Hayden, T.J. 2001. Sexual size dimorphism in fallow deer (Dama dama): do larger, heavier males gain greater mating success? Behav. Ecol. Sociobiol. 29: 266-272.

McRoberts, R.E., Brooks, R.T., and Rogers, L.L. 1998. Using nonlinear mixed effects models to estimate size-age relationships for black bears. Can. J. Zool. 76: 1098-1106.
Moore, N.P., Kelly, P.F., Cahill, J.P., and Hayden, T.J. 1995. Mating strategies and mating success of fallow (Dama dama) bucks in a non-lekking population. Behav. Ecol. Sociobiol. 36: 91-100.

Morin, P.A., Wallis, J., Moore, J.J., and Woodruff, D.S. 1994. Paternity exclusion in a community of wild chimpanzees using hypervariable simple sequence repeats. Mol. Ecol. 3: 469-478.

Murphy, K.M. 1998. The ecology of the cougar (Puma concolor) in the northern Yellowstone ecosystem. Ph.D. dissertation, University of Idaho, Moscow.

Murphy, K.M., Ross, P.I., and Hornocker, M.G. 1999. The ecology of anthropogenic influences on cougars. In Carnivores in ecosystems: the Yellowstone experience. Edited by T.W. Clark, A.P. Curlee, S.C. Minta, and P.M. Kareiva. Yale University Press, New Haven, Conn. pp. 77-101.

Nei, M. 1978. Estimation of average heterozygosity and genetic distance from a small number of individuals. Genetics, 89: 583590.

Paetkau, D., and Strobeck, C. 1994. Microsatellite analysis of genetic variation in black bear populations. Mol. Ecol. 3: 489-495.

Paetkau, D., Calvert, W., Stirling, I., and Strobeck, C. 1995. Microsatellite analysis of population structure in Canadian polar bears. Mol. Ecol. 4: 347-354.

Pemberton, J.M., Albson, S.D., Guinness, F.E., Clutton-Brock, J.H., and Dover, G.A. 1992. Behavioural estimates of male mating success tested by DNA fingerprinting in a polygynous mammal. Behav. Ecol. 3: 66-75.

Poole, J.H. 1989. Mate guarding, reproductive success and female choice in African elephants. Anim. Behav. 37: 842-849.

Pope, T.R. 1996. Sociology, population fragmentation, and patterns of genetic loss in endangered primates. In Conservation genetics: case histories from nature. Edited by J.C. Avise and J.L. Hamrick. Chapman and Hall, New York. pp. 119-159.

Powell, R.A., Zimmerman, J.W., and Seaman, D.E. 1997. Ecology and behaviour of North American black bears: home ranges, habitat and social organization. Chapman and Hall, London, U.K.

Rogers, L.L. 1987. Effects of food supply and kinship on social behaviour, movements, and population growth of black bears in northeastern Minnesota. Wildl. Monogr. No. 97. pp. 1-72.

Ryser, J. 1992. The mating system and male mating success of the Virginia opossum (Didelphis virginiana) in Florida. J. Zool. (Lond.), 228: 127-139.

Sandell, M. 1986. Movement patterns of male stoats, Mustela ermina, during the mating season: differences in relation to social status. Oikos, 47: 63-70.

Sandell, M. 1989. The mating tactics and spacing patterns of solitary carnivores. In Carnivore behaviour, ecology, and evolution. Edited by J.L. Gittleman. Cornell University Press, Ithaca, N.Y. pp. 164-182.

Schenk, A., and Kovacs, K.M. 1995. Multiple mating between black bears revealed by DNA fingerprinting. Anim. Behav. 50: 1483-1490.

Schwagmeyer, P.L. 1988. Scramble-competition polygyny in an asocial mammal: male mobility and mating success. Am. Nat. 131: $885-892$.

Schwagmeyer, P.L. 1995. Searching today for tomorrow's mates. Anim. Behav. 50: 759-767.

Schwagmeyer, P.L., and Woontner, S.J. 1986. Scramble competition polygyny in thirteen-lined ground squirrels: the relative contributions of overt conflict and competitive mate searching. Behav. Ecol. Sociobiol. 19: 359-364. 
Seaman, D.E., Griffith, B., and Powell, R.A. 1998. KERNELHR: a program for estimating animal home ranges. Wildl. Soc. Bull. 26: $95-100$.

Sorensen, V.A., and Powell, R.A. 1998. Estimating survival rates of black bears. Can. J. Zool. 76: 1335-1343.

Travis, S.E., Slobodchikoff, C.N., and Keim, P. 1996. Social assemblages and mating relationships in prairie dogs: a DNA fingerprint analysis. Behav. Ecol. 7: 95-100.

Walsh, P.S., Metzger, D.A., and Higuchi, R. 1991. Chelex 100 as a medium for simple extraction of DNA for PCR-based typing from forensic material. Biotechniques, 10: 506-513.

Webster, M.S., Chuang-Dobbs, H.C., and Holmes, R.T. 2001. Microsatellite identification of extrapair sires in a socially monogamous warbler. Behav. Ecol. 12: 439-446.

Weckerly, F.W. 1998. Sexual-size dimorphism: influence of mass and mating systems in the most dimorphic mammals. J. Mammal. 79: 33-52.

Westneat, D.F., Sherman, P.W., and Morton, M.L. 1990. The ecology and evolution of extra-pair copulations in birds. Curr. Ornithol. 7: 331-369.

Whimsatt, W.A. 1963. Delayed implantation in the Ursidae, with particular reference to the black bear (Ursus americanus Pallus).
In Delayed implantation. Edited by C. Enders. University of Chicago Press, Chicago. pp. 49-74.

Wickings, E.J., Bossi, T., and Dixson, A.F. 1993. Reproductive success in the mandrill, Mandrillus sphinx: correlations of male dominance and mating success with paternity, as determined by DNA fingerprinting. J. Zool. (Lond.), 231: 563-574.

Wielgus, R.B., and Bunnell, F.B. 2000. Possible negative effects of adult male mortality on female grizzly bear reproduction. Biol. Conserv. 93: 145-154.

Wilmer, J.W., Allen, P.J., Pomeroy, P.P., Twiss, S.D., and Amos, W. 1999. Where have all the fathers gone? An extensive microsatellite analysis of paternity in the grey seal (Halichoerus grypus). Mol. Ecol. 8: 1417-1429.

Wilson, G.A., Olson, W., and Strobeck, C. 2002. Reproductive success in wood bison (Bison bison athabascae) established using molecular techniques. Can. J. Zool. 80: 1537-1548.

Young, B.F., and Ruff, R.L. 1982. Population dynamics and movements of black bears in east central Alberta. J. Wildl. Manag. 46: $845-860$.

Zimmerman, J.W., and Powell, R.A. 1995. Radiotelemetry error: location error method compared with error polygons confidence ellipses. Can. J. Zool. 73: 1123-1133. 